\title{
High-rise housing construction as a way of solving the problem of providing people with comfortable habitation
}

\author{
Andrey Misailovov ${ }^{1, *}$ \\ ${ }^{1}$ Moscow State University of Civil Engineering, Yaroslavskoye shosse 26, Moscow, 129337, Russia
}

\begin{abstract}
The article analyzes the role of high-rise construction in solving the problem of providing people with comfortable habitation. High-rise construction is considered as a part of urban environment of big cities, a way of effective land use and development of entrepreneurship, including small and medium-sized enterprises. The economic efficiency of high-rise construction, an increase in budgetary financing and the number of introduced innovations are discussed.
\end{abstract}

\section{Introduction}

Sanctions of some countries helped Russia to begin active development of the construction business. Minister M. Men presented a development strategy and prioritized projects in the construction industry. In this way housing construction has become one of the priority projects and Russian population meet with enthusiasm this project. A new legal framework for housing construction was developed. Agreements are concluded with all the entities that participate in the implementation of projects. Particular attention was paid to high-rise construction. Houses with more than 25 floors and a height more than 75 meters helped to solve the problem of providing housing for people in multi-populated cities.

At least 80 million square meters of housing was created in 2015, 2016, 2017. The amount of funds for the improvement of the urban environment reached 27.2 billion rubles in the year 2017. 50 million rubles was allocated for the training of employees responsible for the implementation of the housing project. The main architects of cities provide the beauty and convenience of urban areas. Their work has been improved, as the State Council of the Russian Federation made a decision on the direct subordination of the chief architects to the governors of cities [1].

High-rise buildings becoming gradually a part of the urban environment actively involve residents in the process of improvement of the adjoining territory - squares, embankments, parks. Municipalities conduct polls and meetings concerning projects of improvement. Public and environmental commissions actively work; only 500 million rubles was allocated for the renewal of parks.

\footnotetext{
* Corresponding author: $\underline{\operatorname{stanu} @ \text { yandex.ru }}$
} 


\section{Materials and Methods}

The construction of high-rise buildings helps to use effectively federal, regional and municipal land in cities. A new methodological and regulatory framework for the construction of high-rise buildings has been developed. It is aimed at the integrated development of the urban environment and the creation of comfortable places for mass recreation. The construction of high-rise buildings has long been considered the prerogative of large enterprises. At present, the Ministry of Construction guides a work on the largescale development of small and medium-sized businesses. Small and medium businesses will receive large state orders.

Throughout most of the twentieth century it was believed that greater economic efficiency have a large enterprise. This opinion was based on the Ford ideas - concept of specialization of workers and a strict sequence of manufacturing operations are possible only in large-scale production. The work of the major companies was connected with the development of innovative processes, scientific and technological progress. Small and medium-sized companies were given niche providing services in the industries producing consumer goods. However, at the end of the century, small and medium businesses have proven the ability to generate innovations and to develop new technologies that allow the economy to make a strong leap forward. An example is the economic growth of Vietnam, Malaysia, South Korea and especially China and India, where the competent investment in the area of software and computer support gave high economic results [2].

In the construction industry over the last two or three decades formed the active medium business sector that possesses the actual qualities as ease of management, flexibility and mobility. In addition, in contrast to the "clumsy" major construction partners focused on mass production, it took advantage of the flexibility of its production system to improve the quality of implementation of individual orders and the expansion of a range of prestigious services and manufactured goods. Medium business is ready to participate in the construction of multi-storey high-rise buildings.

In this process not only the fact of invention was important, but also the process of monitoring the business profitability in the market of production and services where innovations appeared. It should be noted that in the early stages innovations were often associated with the entrepreneurial spirit and creative ingenuity of entrepreneurs in traditional architectural solutions and projects, construction technologies and materials. By varying and combining in new ways traditional solutions, entrepreneurs of small and medium enterprises offered the market a lot of new construction services and products.

The process of diffusion of construction innovations creatively varied - adapted to the new conditions and the wishes of the customer (for example, in accordance with regional, cultural and traditional high-rise construction requirements), supplemented technological findings (based on natural conditions and construction materials). So, numerous innovations in the field of cottage and low-rise construction were widely circulated and led to a massive spread of innovations. It allowed for a short period of time to transform completely the architecture of many Russian country areas. Now there are beautiful, comfortable, high-quality residential complexes. Gradually the balance of competition and cooperation in the relations between construction firms was formed. In many respects the construction sector of small and medium businesses contributed to the creation of the conditions for the improvement of the economy: the development of a competitive environment, the increase in new jobs and expansion of the consumer sector.

Despite the difficulties of transition to market relations and small time period, by the end of the first decade of the XXI century, the contribution of small and medium enterprises in the gross domestic product of the country amounted to more than $20 \%$ (in developed countries - more than $50 \%$ ). This was facilitated by a deliberate process when 
gradually at the state level were established Federal and regional programs to support small and medium enterprises. The experience of foreign financial and credit funds of small business support in the USA, France, Japan was taken into account.

In 2008 in 29 subjects of the Russian Federation programs of support the exportoriented small enterprises were successfully implemented; in 35 subjects the Federal budget supported programs for small business development; in 31 regions acted program of development loans and leasing for small business. The Russian government plans to increase the share of medium-sized businesses to $60 \%$ in economy of the country. Although some economists are skeptical about this, it should be noted that targeting this sector of entrepreneurship to receive large orders will help to increase and expand its development. In this way, the business will be able to participate in high-rise housing construction [3].

At present there are a lot of tax incentives on earnings. For small and medium enterprises are provided:

- special tax regimes, simplified rules of tax accounting, tax returns for individual taxes and levies;

- simplified methods of accounting and reporting;

- simplified procedure for preparing statistical reports;

- peculiarities of privatization of state and municipal property;

- participation in the procedures of placing of orders for delivery of goods, performance of works, rendering of services for state and municipal needs;

- measures to ensure the rights and legitimate interests in the implementation of state control (supervision);

- financial support measures;

- measures for the development of support small and medium enterprises.

More and more entrepreneurs in the Russian Federation use the basic principles of the state policy on development of small and medium entrepreneurship enshrined in the law:

- responsibility for the support of small and medium enterprises between the Federal bodies of state power, bodies of state power of subjects of the Russian Federation and bodies of local self-government;

- liability of public authorities of the Russian Federation, bodies of state power of subjects of the Russian Federation, bodies of local self-government for providing enabling environment for the development of small and medium enterprises;

- participation representatives of small and medium enterprises, associations of entrepreneurs, other non-profit business organizations, including chambers of Commerce and the Association of employers in the development of state and municipal policies for the development of small and medium enterprises and expert examination of draft normative legal acts on the issues of development of subjects of small and average business;

- equal access of small and medium-sized enterprises to support [4].

In the year 2015 for small and medium business there were made tax holidays, which covers the period up to 2020. In all regions were created favorable conditions for entrepreneurial activity in housing construction to increase the competitiveness of the economy. In Moscow, the volume of construction of high-rise buildings grows every year. High-rise construction has become an important part of the project of providing people with habitation. Since 2011 there was adopted and implemented a program "Stimulation of economic activity", the part of which was the sub-program "Development of small and medium enterprises". This sub-program aims to increase the competitiveness of the economy of Moscow and the welfare of its population by the creation of favorable conditions for entrepreneurial activity and sustainable development of small and medium enterprises, including micro enterprises and individual entrepreneurs. In this regard, it is important to mention the significance of training of entrepreneurship in universities. In Moscow state university of civil engineering students study various aspects of urban 
construction, analyze the economic indicators of the feasibility of construction (including altitude), the calculation of estimated costs with basic prices for tangible and intangible resources.

The successful implementation of the program is connected with the following indicators:

- reduced and simplified administrative procedures for implementation of investment projects and starting business;

- stimulated business activity and business support;

- created competitive environment;

- improved infrastructure conducive to business development;

- training, retraining and re-employment resources in favor of high-performance industries [5].

These changes have created favorable conditions for development of entrepreneurship of small and medium construction companies: annual sustainable business development was reached, contribution to the economy of the city was increased, the number of employed people in small and medium construction business was increased, transparency of the activity of enterprises was increased. The activities of small and medium construction enterprises by turnover Finance, number of actors, the share of the employed in small and medium businesses of the total population in the industry are annually monitored. Some medium-sized enterprises already have experience of participation in the construction of high-rise residential buildings. It is supposed to determine the position of Russia in the "Doing Business" ranking during the evaluation of the sub-program dedicated to the development of enterprises.

In general, in the process of implementation of the sub-program it is planned to increase the following indicators:

- the turnover of small and medium-sized businesses with 6870 billion rubles to 8360 billion;

- the number of actors from 360 to 420 thousand;

- to increase the share of the employed in small and medium businesses up to $60 \%$;

However, the unfinished tasks of a General nature on the formation favorable environment for the development of small and medium enterprises can be highlighted: Federal authorities are still configured to support mostly big business and small and medium enterprises are supported by regional and local authorities that often lack the administrative resources and economic potential; significantly reduce the development of medium business high cost loans, and the inability to pay a Deposit or provide a guarantor for the loan while the unions of small enterprises and special funds currently do not act as guarantors for loans; there are no special banks to service small and medium businesses [6].

\section{Results}

At present, the construction industry solves a huge task. The national project - the program "Housing for Russian family" was ready since 2015 for implementation. It was prepared by the Ministry of construction and housing and coordinated with all departments. Despite the fact that housing provision Russians is gradually changing for the better, as evidenced by the growth in mortgage lending and housing construction, the request for the new, comfortable and affordable housing is still high. Almost 2/3 of citizens wants to improve their housing conditions, but do not have the capability. The program "Housing for Russian family" will allow 460 thousand Russian families to improve the living conditions. New housing program is designed to 2017 inclusive. 36 regions got applications for participation in the program. Until the end of 2017 year in these regions it is planned to build at least 25 million square meters of economy class housing with the entire social and engineering 
infrastructure. Those families who are unable to buy apartments on the market conditions can take advantage of this opportunity. In accordance with the social orientation of the program the cost of one square meter of housing will not exceed 30 thousand rubles. It is planned to build 5 million square meters in 2015 year, 6 million in 2016 and in 201714 million. In large cities, high-rise construction has become an important part of the project of providing people with comfortable housing.

Families in which the housing for one of its members does not exceed the maximum amount set in a specific region, but not more than 18 square meters per person can participate in the program. In addition, in these apartments could be settled citizens, living in substandard housing, families with two or more minor children. The total income of such families and different financing mechanisms - mortgage loan, the parent capital and other forms of state support should allow them to buy an apartment. Thus, people can choose apartments in high-rise buildings both expensive and cheap [6].

The government hopes that citizens will mostly use mortgage lending opportunities. The sum of issued credits in Russia in 2015 was more than 2.8 trillion rubles. Despite the large magnitude of the sum, the credits are too expensive, largely due to insufficient development of the mortgage market. According to the Agency for housing mortgage lending, the share of mortgage loans in 2016 was about $9 \%$. In 2017, the law was amended to improve the protection of the rights of participants in the shared construction of high-rise buildings. However it should be noted the increase in the number of mortgage agreements in 2017.

It is important to stress that program "Housing for Russian family" is planned to implement at the expense of developers and funds of the parent capital in public infrastructure provision on the plots. It is considered that total volume of long-term borrowings will be 100 billion rubles for the construction of infrastructure, more than half of which were previously allocated funds of Vnesheconombank, and the rest will be brought on the market.

Currently in the high-rise construction is actively growing entrepreneurial activity, rapid deployment and commercialization of results of scientific research and development connected with extension, renewal of product range and the quality improvement of construction materials and services; also there is an improvement in their production technology and appearance of effective finds in the system of the sale of goods and services. In the new project of a high-rise housing construction can be used entrepreneurial innovations that improve the quality of building.

Among the innovations it should be noted that some experimental objects of high-rise housing are ready to be built in Moscow with the use of nanotechnology, they may be the prototype of the housing of the new generation for the whole country. About thirty different kinds of innovative technological solutions will be applied in high-rise construction. Among them - air filters which clean the air in rooms and disinfect it with ultraviolet light, the separate water filtration systems, enriching water with minerals and giving the opportunity to clean it up to drinking. In the high-rise construction will be applied innovative technologies allowing to reduce operating costs of the buildings and to increase the intervals overhaul and current repairs. Such technologies were mainly used in the construction of commercial buildings and now it is planned to apply them in the construction of municipal buildings and social facilities. It will give the opportunity to determine the pros of used innovative approaches and to adjust the vector of development of technologies to meet new challenges for the high-rise construction of the city's facilities. In the high-rise construction of residential areas (especially in the implementation to mass high-rise construction) is interesting the technology that allows personalizing the look of the high-rise buildings. Data analysis of consumer demand in the property market show that people prefer high-rise residential complexes that are designed with the latest innovative 
technology, gradually moving away from the format of the purchase of a typical apartment in a typical house. So, the development of standards for the implementation of such projects is of importance.

Important findings are related to the production of environmental technologies that do not harm the nature. It is known that the enterprises for manufacture of building materials must meet severe requirements to comply with environmental safety. Using environmentally friendly building materials solves the problem of the health of descendants. This primarily refers to synthetic materials. They have adverse effects on the environment, require more energy expenditure, harmfully recycled and are not capable to quick natural self-destruction.

Usually, preference is given to the organization of space in a way that it meets the requirements of comfort for both inside the apartment and in public areas. Typically, innovative high-rise construction uses a high quality products, different first-class characteristics and interesting design. When choosing material the number of functions it performs is counted (for example, could be glazed with the option of a balanced light distribution). When planning the adjoining areas thought out landscaping, convenient location, public areas, safety of residents. Much attention is paid to the presence of playgrounds and sports grounds, walkways and recreational areas, Jogging and Cycling trails. In addition to high-rise residential buildings in the infrastructure are included kindergartens, schools, sports facilities, shopping facilities. An important direction in modern high-rise construction is individualization, in which the layout of the apartments provides a variety of solutions. For example, in one house can be represented by more than 20 variants of layouts, among which multi-level apartment, apartment with separate entrance, panoramic apartment, Studio apartments, one-roomed flat.

\section{Discussions}

However, it should be noted that with the increase of the possibilities of innovations and their number in high-rise residential construction the price of apartment in a building designed by the latest technology, increases. Under these conditions, the economy of highrise construction becomes an important problem of optimizing the cost of construction. It is important that during construction, the objective was to introduce the maximum amount of eco-friendly solutions at every stage of construction and implement them with minimal cost. The account of only some aspects of the construction helps to form a conclusion about the possibility of solving such problems.

Economy advantages in high-rise buildings can give the use of energy-saving system. The increase in the thickness of the insulation of external walls, replacement of inefficient ventilation system and windows provides savings of thermal energy by $25-27 \%$. The use of new building materials or an innovative combination of traditional building materials is economically reasonable. For example, the reduction in the number of fixtures by increasing the amount of concrete in those places where the size of the reinforced concrete structure does not matter; good results are obtained by using fiberglass reinforcement instead of steel (rebar at equal load-bearing characteristics is thinner, lighter, more corrosion-resistant).

\section{Conclusion}

The construction of monolithic buildings, in which is used cellular concrete instead of the standard concrete can be cost-effective. This kind of building material while maintaining the strength improves thermal insulation and facilitates the design of the house and this 
solves the problem of the quality of mobile communication that occurs in the monolithic structures.

Thus, the implementation of large-scale housing projects in modern high-rise construction requires a combination of innovative technologies that allow creating a comfortable environment for consumers and a wide range of capabilities for developers and they will receive not only the gratitude from consumers, but also the financial gain. The construction of high-rise buildings allows attracting more than $80 \%$ of extrabudgetary financing, solving the social problem of improving the living conditions of citizens and promises profit to investors.

\section{References}

1. Z.I. Ivanova, O.V. Yudenkova, A.D. Ishkov, E.A. Shnyrenkov, International Education Studies. 5, 232-239 (2015)

2. A.D. Ishkov, T.N. Magera. Procedia Engineering, 117, 148-153 (2015)

3. M.I. Kamenetskii, N.Y. Yaskova, Studies on Russian Economic Development, 26(2), 124-131 (2015)

4. M. Aladdess. Engineering Systems and Structures, 3(16), 38-43, (2014)

5. A. Vorotynseva, M. Aladess. Finances, Economics, Strategy, 6, 48-54, (2016). 